\section{Assessment of the Sustainable Financial- Aspect of Polders in the Province of DKI Jakarta}

\author{
Wied Wiwoho Winaktoe ${ }^{a^{*}}$, Bart Schultz ${ }^{b}$, \\ F.X. Suryadi ${ }^{\text {b }}$
}

${ }^{a, b, c}$ Chair Group of Land and Water Development, UNESCOIHE, 2601 DA Delft, The Netherlands

Received: February 12, 2016/ Accepted: July2, 2018

\begin{abstract}
Assessment of the financial aspects of polders was undertaken with a Sustainable Financial Model (SFM) application to analyze individual polders in the Province of DKI Jakarta in order to find better local values which in turn can improve the general baseline. This assessment was conducted in the polders of Muara Karang, Pluit, Pulo Mas and Duri Kosambi. Among the baseline values which critically needed to be adjusted was the segment of Gov_bdg >>Sust.Inf. Two scenarios were evaluated: (i) regular-type and (ii) NPCE-type. The method of assessment used SEM with PLS as a statistical approach to analyze the data.

Overall, the results indicated that the more cooperative and integrated NPCE approach to Local Government investment in polder management was more likely to have positive effects.
\end{abstract}

Keywords: Jakarta; polder; financial

\begin{tabular}{|c|c|c|}
\hline$D K I$ & & $\begin{array}{l}\text { Daerah Khusus Ibukota (Special Capital } \\
\text { Region) }\end{array}$ \\
\hline TBL & : & Three Bottom Line \\
\hline NPCE & & $\begin{array}{l}\text { Program Nasional Pemberdayaan } \\
\text { Masyarakat (PNPM) or Natioanl Program } \\
\text { for Community Empowerment }\end{array}$ \\
\hline CSEG & & $\begin{array}{l}\text { Kelompok Swadaya Masyarakat (KSM) or } \\
\text { Community Self-Empowered Group }\end{array}$ \\
\hline St.Dev. & : & Standard Deviation \\
\hline PLS & : & Partial Least Squares \\
\hline Gov_bdg & : & $\begin{array}{l}\text { Government budget for flood protection } \\
\text { and drainage control }\end{array}$ \\
\hline PP & : & Partnership potentiality \\
\hline СРP & : & Community participation potentiality \\
\hline Sus. Inf. & : & $\begin{array}{l}\text { Sustainability of flood protection and } \\
\text { drainage infrastructures }\end{array}$ \\
\hline MK & : & Muara Karang \\
\hline KOS & : & Duri Kosambi \\
\hline PM & : & Pulomas \\
\hline PL & : & Pluit \\
\hline _bdg & : & $\begin{array}{l}\text { Predictor of Local Government's regular- } \\
\text { type budget for flood protection and urban } \\
\text { drainage }\end{array}$ \\
\hline _sme & : & Predictor of number of enterprises \\
\hline -mrw & : & $\begin{array}{l}\text { Predictor of number of households whose } \\
\text { wages are above the Minimum Regional } \\
\text { Wage }\end{array}$ \\
\hline _is & $:$ & $\begin{array}{l}\text { Predictor of number of households that } \\
\text { occupy the floodplain }\end{array}$ \\
\hline
\end{tabular}

\section{Introduction}

'A polder is a level area, in its original state subject to high water levels (permanently or seasonally, originating from either groundwater or surface water), but which through impoldering is separated from its surrounding hydrological regime in such a way that a certain level of independent control of its water table can be realized'[1]. After 35 years of polder development in the Province of DKI Jakarta a start has been made to incorporate issues of sustainability as shown in the Spatial Planning document of DKI Jakarta 2010-2030 [2]. Aside from the technical aspects, which are considered to be sufficiently understood, the draft of the document expected that financial and institutional aspects would be formulated according to the precedent of a Polder Board Model [3] [4].

Until 2014 - five years after the draft was circulated for public hearing, or 3 years after the Spatial Planning document of DKI Jakarta 2010-2030 was legalized as Provincial Regulation - the corresponding policies, which were expected to support the development of the Polder 
Board's essential features, was still unavailable [5]. As the Provincial Government of DKI Jakarta plans and allocates budgets for flood protection and urban drainage it would be useful to assess the budgetary impacts on certain essential features of polder board model.

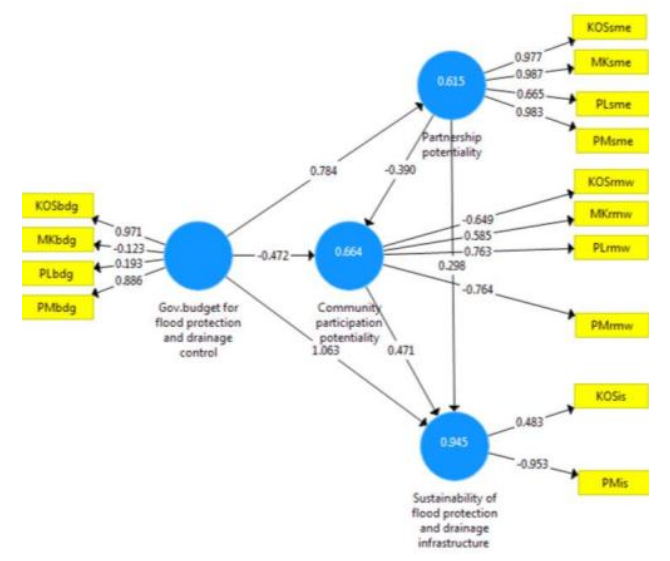

Figure 1 SFM's Weight value for DKI Jakarta urban polders

A Sustainable Financial Model (SFM) for DKI Jakarta urban polders found that the baseline of the government budget for flood protection (Gov_bdg) with respect to sustainability of flood protection (Sust.Inf) for the period 2009-2014 was given a Weight $=+1.063$ and $\mathrm{T}$-value $=0.649$ [6]. This Weight's sign value indicates that the Local Government (Provincial) program for flood protection and drainage control may ineffectively alleviate the problems for illegal settlements who occupied the floodplain. In reality, Local Governments built urban polder infrastructure which was encroached on by illegal settlers or squatters [7] [8] [9]. The growth of illegal settlements narrowed the rivers and retention ponds [10], intense sedimentation occurred, and urban drainage disappeared or became clogged with solid waste [11] [12] [13]. These impacts threaten the polder system, increase the risk of malfunction, and can render the infrastructure ineffective for the long term.

This situation demands improvement which leads to the need to assess possible ways to alleviate the issues of illegal dwellers through Government programs. The Local Government role is important due to (i) its position as public budget holder and policy maker [14] [15] and (ii) obligation to perform a minimum service related to inundation as stated by regulation [16]. Statistically the expected Weight would be lower and have a negative sign.

\section{Sustainable Local Government program}

\subsection{Empowerment as a difference factor}

The preliminary analysis of Polders of Muara Karang (MK) and Pluit (PL) showed that the ability to develop, operate and maintain flood protection and urban drainage schemes corresponded with partnership and stakeholders' affordability, as well as with reduction of illegal structures in the floodplain [17]. However, programs to deal with illegal dwellers or squatter are typically outside the scope of regular flood protection and drainage control. One clear solution for the illegal dwellers was relocation, mostly to public rental housing [18] [19] in locations away from the previous settlements. In their later houses, former illegal dwellers still faced economic challenges in terms of monthly rent payments which could accumulate for months [20].

Lists of priorities among the poor, including illegal dwellers, on the floodplain put temporary unconditional cash transfers as first priority, housing and health care as second and third priorities consecutively [21]. Furthermore, house rent budget allocation has to compete with other expenditures such as food, education, health, etc. Economic empowerment was seen to be a key issue that effective Local Government policy needs to address and which should be internalized into programs and budgets.

The current Local Government policy, programs, and budgets for flood protection and drainage control are largely detached from economic empowerment despite of their development through bottom-up stakeholders' fora [22]. However, a program started in 2007 called PNPM (English: National Program for Community Empowerment, NPCE) was implemented for alleviating the poor and has been continuing until now (year 2017)[23]. NPCE consisted of (i) environmental programs which included drainage contruction, (ii) social programs, and (iii) economic programs [24]. Each program/project was developed through stakeholder meetings which included the poor as a mandatory requirement. The project was planned and funded by collaborative groups (National Government, Local Government, community, and private sectors) and implemented mainly by the community. The comparative characteristics between regular-type and NPCE-type projects for flood protection and drainage control are summarized in Table 1.

Table 1 Comparative characteristics between regular-type and NPCE-type programs

\begin{tabular}{lll}
\hline Aspects & Regular-type & NPCE-type \\
\hline $\begin{array}{l}\text { Proposal } \\
\text { Initiative }\end{array}$ & Stakeholders forum & $\begin{array}{l}\text { Community, } \\
\text { including the poor }\end{array}$ \\
$\begin{array}{l}\text { Proposal } \\
\text { Finalization }\end{array}$ & $\begin{array}{l}\text { Local Government's } \\
\text { technical unit }\end{array}$ & $\begin{array}{l}\text { Community, } \\
\text { including the poor }\end{array}$ \\
$\begin{array}{l}\text { Funded by } \\
\text { Local Government's } \\
\text { public budget and } \\
\text { expenditure }\end{array}$ & $\begin{array}{l}\text { Collaborative } \\
\text { (National Gov., Local } \\
\text { Gov, community, } \\
\text { private sectors, etc) }\end{array}$ \\
& \multicolumn{1}{c}{$\begin{array}{l}\text { Certified service } \\
\text { provider }\end{array}$} & Community \\
\hline
\end{tabular}


Table 1 indicates that for the same infrastructure, there were 2 possible ways to deliver the project: regular-type and NPCE-type. NPCE-type programs were implemented by the community at neighbourhood level through KSM (English: Community Self-Empowered Group, CSEG) [25]. The number of independent CSEG after program/project implementation was also one of NPCE-type's successful indicators. In order to promote better SFM influence of Gov_bdg towards Sust.Inf then, NPCE-type projects could be feasible candidates because of its internalized empowerment factor.

\subsection{Triple Bottom Line (TBL) impacts}

The Triple Bottom Line (TBL) is a typical formulation of sustainability, incorporating economic, environmental and social components. Regular-type Local Government policy, programs, and budgets for flood protection and drainage control may only address the TBL's environmental pillar, rather than a holistic perspective.These programs have typically been run by the Provincial Office of Water Resources Management (POWRM) hence support for social and economic aspects is expected to come from other departments outside POWRM. In this way, integration in terms of schedule, program design and evaluation may be difficult to achieve. On the other hand, NPCE-type environmental, social, and economic programs may reflect the TBL in a more integrated way . Each program acts as an entry point providing impact to others simultaneously.

Finding better values for the influence of Gov_bdg on Sust.Inf through SFM assessment would give feedback to the Local Government's current practices which could lead to potential improvement for urban polders in general. Since 2014 NPCE entered the project phase in which Local Governments were expected to internalize and continue the programs as their own [26]. Comparative analysis with NPCE-type programs may enable its mainstreaming into Local Government practices.

Assessment of the financial sustainability of polders could ensure financial support for preservation of retention basins, further leading to securing people from the shortand long-term ravages of nature, and deterioration of the natural environment. From the socio-economic perspective, Local Government budget realization for flood protection and urban drainage could provide a protected working place where economic activities can continue to take place and attract investments which will lead to assured basic income for various income groups. The construction stage may also provide seasonal jobs as shown in NPCE-type projects.

\section{Research Question}

Assesment of sustainable financial aspects in the DKI Jakarta's urban polders is focused on finding a better value for the influence of government budgets on sustainability of infrastructure (the weight Gov_bdg>>Sust.Inf) which is expected to be lower than the general baseline Weight
$(+1.063)$. For this purpose, the research question in this study was: what value would Gov_bdg>>Sust.Inf attain under possible scenarios involving either regular-type or NPCE-type programs in each urban polder?

\section{Methods \\ 4.1. Case studies and data}

The case studies analysed here involve polders of Muara Karang (MK), Pluit (PL), Duri Kosambi (KOS) and Pulo Mas (PM) which were considered to be representative of DKI Jakarta's areas and management types, respectively: Northprivate, North-public, West-public, and East-public. All data were collected during the period 2009-2014 through official documents and interviews at neighbourhood level, except for regular-type projects' budgets and NPCE-type budget data which were retrieved from official online sources [27][28]. Variables being analyzed as predictors consist of budget for flood protection and urban drainage (_Gov_bdg), number of enterprises (_sme), number of households whose wages are above the Minimum Regional Wage (_mrw) and number of households that occupy the floodplain zone (_is).

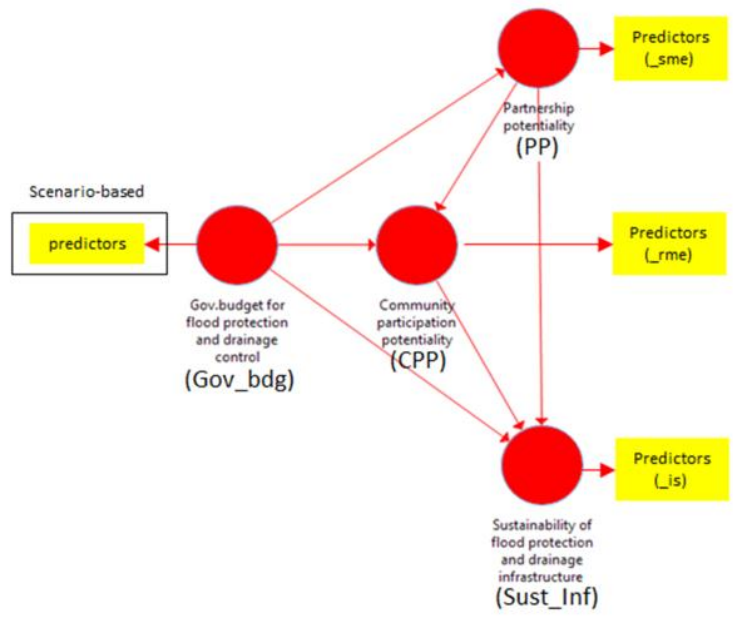

Figure 2 SFM schematization, variables and predictors

Table 2 Regular-type and NPCE-type data for Gov_bdg>>Sust.Inf. simulation

\begin{tabular}{lll}
\hline \multicolumn{1}{c}{ Type } & \multicolumn{1}{c}{ Data/ } & \multicolumn{1}{c}{ Code in SFM } \\
Indicators & \\
\hline $\begin{array}{l}\text { Regular- } \\
\text { type }\end{array}$ & $\begin{array}{l}\text { Local Government budget } \\
\text { for flood protection and } \\
\text { drainage control }\end{array}$ & $\begin{array}{l}\text { _flood_drain_- } \\
\text { budget_LocGov }\end{array}$ \\
$\begin{array}{l}\text { NPCE- } \\
\text { type }\end{array}$ & $\begin{array}{l}\text { Local Government's } \\
\text { implemented } \\
\text { environmental budget }\end{array}$ & _implemented_env_ \\
\hline
\end{tabular}


Local Government's BLM_implemented_BLM_ budget

budget_LocGov

The characteristics identified in Table 1 on regular-type and NPCE-type programs are used to create possible scenarios with the Gov_bdg variable (Figure 2).

\subsection{Analytical model, scenarios and St.Dev}

Assessment to find a better value for Gov_bdg>>Sust.Inf used SFM as an analytical model. SFM is basically a Structural Equation Model (SEM) with Partial Least Squares (PLS) [29] as its statistical calculation approach [30]. SEMPLS, through path analysis, is equipped with the capability of providing direct/indirect effects [31] which can be translated into alternative policy scenarios, including budget, institutional and time constraints. The schematic feature of SEM-PLS is also useful for communicating the results to various stakeholders with different backgrounds. Limited available data (period 2009-2014) was another reason for utilizing the SEM-PLS as it is advantageous for small sample sizes [32].

Table 3 Possible scenarios of indicator input

\begin{tabular}{cll} 
Scenarios & \multicolumn{1}{c}{ Data/ } & Remarks \\
& \multicolumn{1}{c}{ Indicators Code } & \\
2 & _flood_drain_budget_LocGov & $\begin{array}{l}\text { Regular } \\
\text { practice }\end{array}$ \\
& _implemented_env_budget_LocGov & $\begin{array}{l}\text { NPCE } \\
\text { practice }\end{array}$ \\
& _implemented_BLM_budget_LocGov & \\
\hline
\end{tabular}

The Gov_bdg>>Sust.Inf segment was assessed by using scenarios which were based on combinations between regular-type and NPCE-type program data. Ideally, NPCEtype programs would include environmental, social and economic programs all together as indicators in SFM. However, during the period of 2009-2014, economic programs within each polder were recorded as zero values which excluded them as indicators in SFM. It is important to note that squatters were not eligible for NCPE hence in reality the programs were mutually exclusive. However, the poor and illegal dwellers on the floodplain (squatters) shared similar characteristics, except for land tenureship, and priorities in terms of unconditional cash transfer/support [33].

SFM assessment was simulated using SEM-PLS to find the Weight and T-value of Gov_bdg>>Sust.Inf for different scenarios. The T-value significance is measured at $\alpha=5 \%$ or $\mathrm{T}$-value $($ table $)=1.96$. Path analysis is reported to explore direct and indirect effects from Gov_bdg to Sust.Inf in order to identify how better value may be created. The model emulates field data, so the outputs were analyzed and interpreted in accordance with the empirical conditions.

Table 4 Predictor's St. Dev. of PP, CPP and Sust.Inf variables

\begin{tabular}{|c|c|c|c|}
\hline Code & Unit & $\begin{array}{c}\text { Predictors } \\
\text { St.Dev. }\end{array}$ & Remarks \\
\hline MK_sme & & 1315.00 & Included \\
\hline KOS_sme & & 680.00 & Included \\
\hline PM_sme & enterprises & 194.00 & Included \\
\hline PL_sme & & 489.00 & Included \\
\hline MK_rmw & & 1.34 & Included \\
\hline KOS_rmw & & 10.795 & Included \\
\hline PM_rmw & $\%$ & 1.511 & Included \\
\hline PL_rmw & & 0.088 & Included \\
\hline MK_is & & 0.00 & Excluded, ST.Dev ${ }^{2}=0$ \\
\hline KOS_is & & 21.667 & Included \\
\hline PM_is & households & $1,154.693$ & Included \\
\hline PL_is & & 0.00 & Excluded, ST.Dev ${ }^{2}=0$ \\
\hline
\end{tabular}

Based on standard deviation (St.Dev) requirements, several indicators have to be excluded due to zero value St.Dev (Table 4) or unavailable data as the NPCE-type's programs were conducted outside the polder area (Table 5). MK_is and PL_is are excluded because their raw data were constant; the former and latter examples had usable data outside the research period (2009-2014). This would lead to discontinuing SFM analysis of the two polders in terms of finding better values for Gov_bdg>>Sust.Inf.

\section{Results and Discussions}

This section provides theinitial Weight value sunder scenario 1 (Table 3) or normal SFM simulation as its predecessor in Figure 1. Following Table 4 then, MK and PL were estimated to be discontinued in the context of finding better values for Gov_bdg>>Sust.Inf. The next step is continuing to assess PM and KOS according to scenarios in Table 3 . 
Table 5 Predictor's St. Dev. of Gov_bdg variable

\begin{tabular}{|c|c|c|c|}
\hline Code & Unit & St.Dev. & Remarks \\
\hline $\begin{array}{l}\text { MK_flood_drain_ } \\
\text { budget_LocGov }\end{array}$ & & 812.12 & Included \\
\hline $\begin{array}{l}\text { KOS_flood_drain_ } \\
\text { budget_LocGov }\end{array}$ & & $7,850.30$ & Included \\
\hline $\begin{array}{l}\text { PM_flood_drain_ } \\
\text { budget_LocGov }\end{array}$ & & $1,904.11$ & Included \\
\hline $\begin{array}{l}\text { PL_flood_drain_ } \\
\text { budget_LocGov }\end{array}$ & & $4,002.02$ & Included \\
\hline $\begin{array}{l}\text { MK_implemented_env__ } \\
\text { budget_LocGov }\end{array}$ & & n.a. & Excluded \\
\hline $\begin{array}{l}\text { KOS_implemented_env_ } \\
\text { budget_LocGov }\end{array}$ & & $47,883 \cdot 52$ & Included \\
\hline $\begin{array}{l}\text { PM_implemented_env_ } \\
\text { budget_LocGov }\end{array}$ & Rp.x $10^{6}$ & $130,922.11$ & Included \\
\hline $\begin{array}{l}\text { PL_implemented_env_ } \\
\text { budget_LocGov }\end{array}$ & & $76,693 \cdot 56$ & Included \\
\hline $\begin{array}{l}\text { MK_implemented_BLM_ } \\
\text { budget_LocGov }\end{array}$ & & n.a. & Excluded \\
\hline $\begin{array}{l}\text { KOS_implemented_BLM_ } \\
\text { budget_LocGov }\end{array}$ & & $42,687.49$ & Included \\
\hline $\begin{array}{l}\text { PM_implemented_BLM_ } \\
\text { budget_LocGov }\end{array}$ & & $64,705 \cdot 53$ & Included \\
\hline $\begin{array}{l}\text { PL_implemented_BLM_ } \\
\text { budget_LocGov }\end{array}$ & & $55,602.76$ & Included \\
\hline
\end{tabular}

Table 6 Latent/manifest variables and predictors

\begin{tabular}{ll}
\hline Latent/manifest variables & Predictors \\
\hline $\begin{array}{l}\text { Government budget for flood protection and } \\
\text { drainage control }\end{array}$ & As in Table 5 \\
$\begin{array}{ll}\text { (Manifest variable }=\text { Gov_bdg) } \\
\text { Partnership potentiality } \\
\text { (manifest variable }=\text { PP) }\end{array}$ & MKsme \\
& KOSsme \\
& PMsme \\
\hline
\end{tabular}

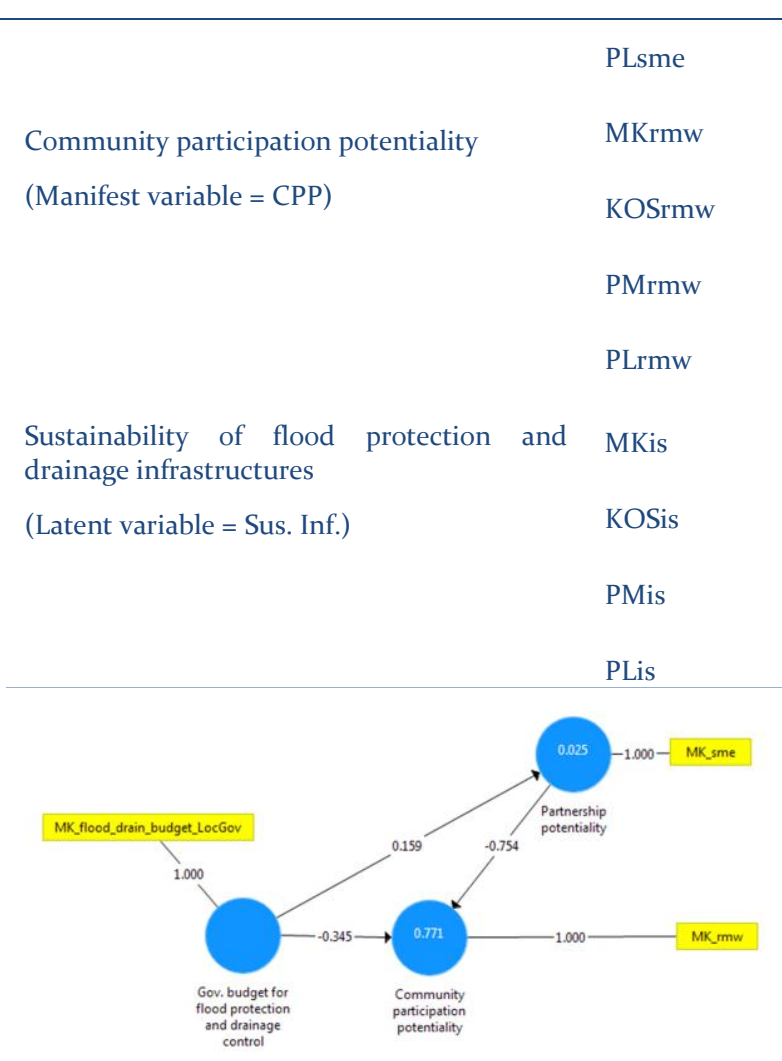

Figure 3 Scenario 1: Muara Karang polder (MK) Weight value

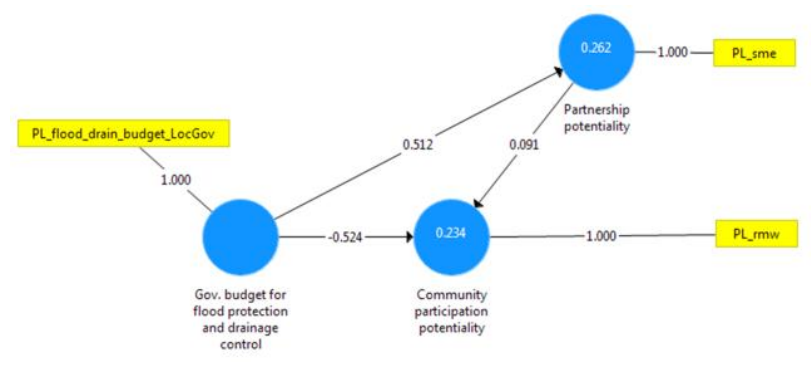

Figure 4 Scenario 1: Pluit polder (PL) Weight value 


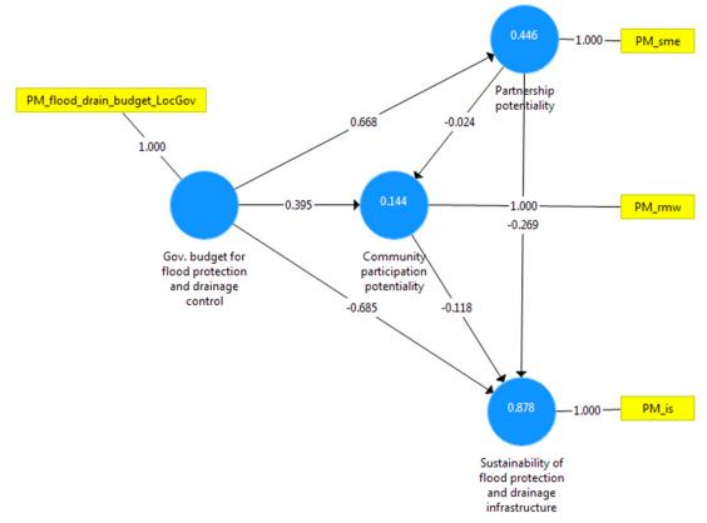

Figure 5 Scenario 1: Pulo Mas polder (PM) Weight value

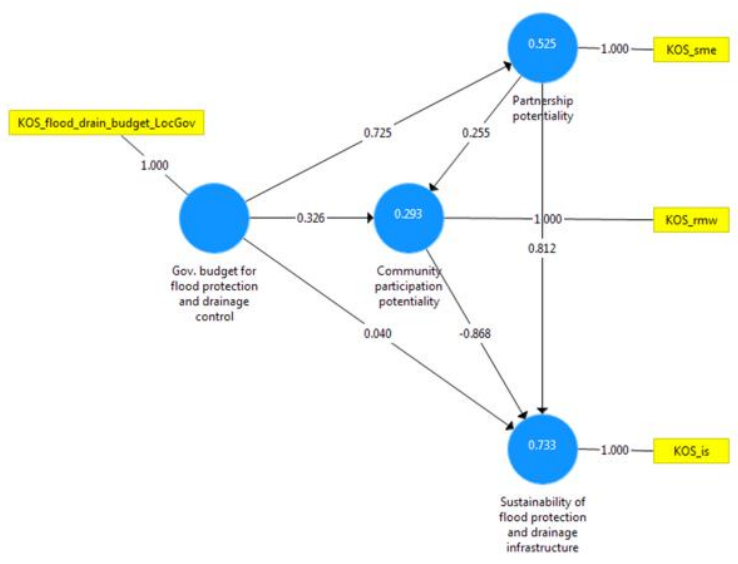

Figure 6 Scenario 1: Kosambi (KOS) polder Weight value

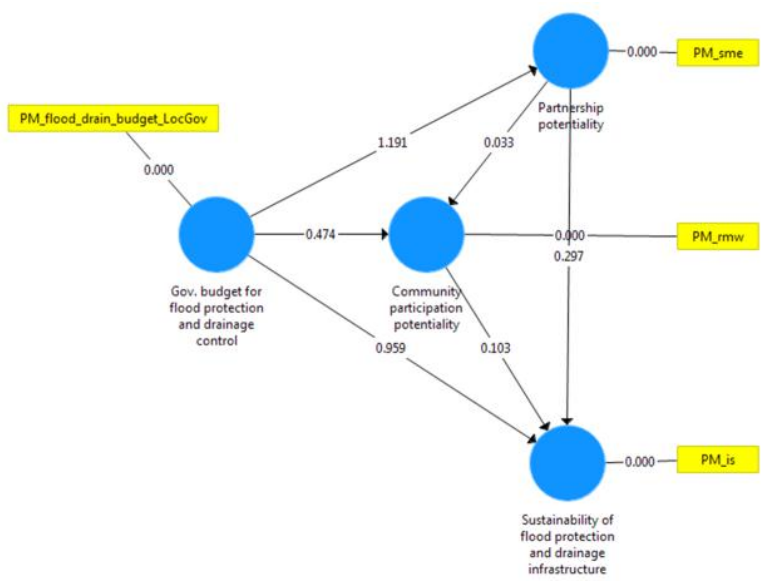

Figure 7 Scenario 1: Pulo Mas (PM) polder T-value

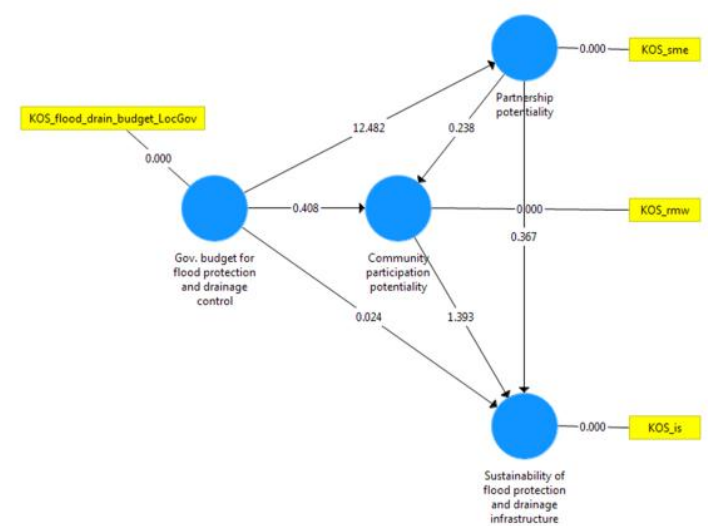

Figure 8 Scenario 1: Kosambi (KOS) polder T-value

Table 7 Scenario $1: \mathrm{R}^{2}$, Weight and T-value

\begin{tabular}{|c|c|c|c|c|c|}
\hline & MK & PL & PM & KOS & Baseline \\
\hline $\begin{array}{ll}\mathrm{R}^{2} & \text { for } \\
\text { Sust.Inf. } & \end{array}$ & n.a. & n.a. & $87.8 \%$ & $73.3 \%$ & $94.5 \%$ \\
\hline $\mathrm{R}^{2}$ for $\mathrm{CPP}$ & $77.1 \%$ & $23.4 \%$ & $14.4 \%$ & $29 \cdot 3 \%$ & $66.4 \%$ \\
\hline $\begin{array}{l}\text { Gov_Bdg >> } \\
\text { PP }\end{array}$ & +0.159 & +0.512 & $\begin{array}{r}+0.668 \\
(1.1 .91)\end{array}$ & $\begin{array}{r}+0.725 \\
(12.482) \\
*\end{array}$ & $\begin{array}{r}+0.784 \\
(6.956)^{*}\end{array}$ \\
\hline $\begin{array}{l}\text { Gov_Bdg >> } \\
\text { CPP }\end{array}$ & -0.345 & -0.524 & $\begin{array}{l}+0.395 \\
(0.474)\end{array}$ & $\begin{array}{l}+0.326 \\
(0.408)\end{array}$ & $\begin{array}{r}-0.472 \\
(0.910)\end{array}$ \\
\hline $\begin{array}{l}\text { Gov_Bdg >> } \\
\text { Sust.Inf. }\end{array}$ & n.a. & n.a. & $\begin{array}{l}-0.685 \\
(0.959)\end{array}$ & $\begin{array}{l}+0.040 \\
(0.024)\end{array}$ & $\begin{array}{r}+1.063 \\
(0.649)\end{array}$ \\
\hline $\mathrm{PP}>>\mathrm{CPP}$ & -0.754 & +0.091 & $\begin{array}{l}-0.024 \\
(0.033)\end{array}$ & $\begin{array}{l}+0.255 \\
(0.238)\end{array}$ & $\begin{array}{l}-0.390 \\
(0.533)\end{array}$ \\
\hline PP $\gg$ Sust.Inf. & n.a. & n.a. & $\begin{array}{r}-0.269 \\
(0.297)\end{array}$ & $\begin{array}{l}+0.812 \\
(0.367)\end{array}$ & $\begin{array}{l}+0.298 \\
(0.085)\end{array}$ \\
\hline $\begin{array}{l}\text { CPP >> } \\
\text { Sust.Inf. }\end{array}$ & n.a. & n.a. & $\begin{array}{r}-0.118 \\
(0.103)\end{array}$ & $\begin{array}{l}-0.868 \\
(1.393)\end{array}$ & $\begin{array}{l}+0.471 \\
(0.118)\end{array}$ \\
\hline
\end{tabular}

${ }^{*}$ : significant at $\alpha=5 \%$ or $\mathrm{T}$-value (table) $=1.96$

Initial (scenario 1) simulation reveals that SFM assessment of individual polders has better values compared to the baseline as follows: KOS's Gov. Bdg >> PP, PM's Gov. Bdg >> CPP, KOS's Gov. Bdg >> Sust.Inf., KOS's PP >> CPP, KOS's PP $>>$ Sust.Inf., KOS's CPP $>>$ Sust.Inf, with significant results obtained by KOS's Gov_bdg $>>P P$. This means that the Gov_bdg during period of 2009-2014 has significantly contributed to the development of private sectors in the KOS polder. Higher values in individual polders as compared to the Local Government SFM baseline value may be an important learning for the improvement of other polders.

Regarding the Gov_bdg>>Sust. Inf., the initial scenario finds that MK and PL cannot be further futher analysed because the Sust.Inf variable cannot be processed. Table 7 shows that regarding Gov_bdg>>Sust.Inf., PM has -o.682 (< $+1.063)$ while KOS has +o.040 (<+1.063). However, empirically the PM alleviation of illegal dwellers was an impact of particular programs outside of flood protection 
and drainage control (MK_flood_drain_Budget_LocGov) [34]. Despite its better value as compared to the general baseline, this value cannot be taken into consideration due to this external influence.

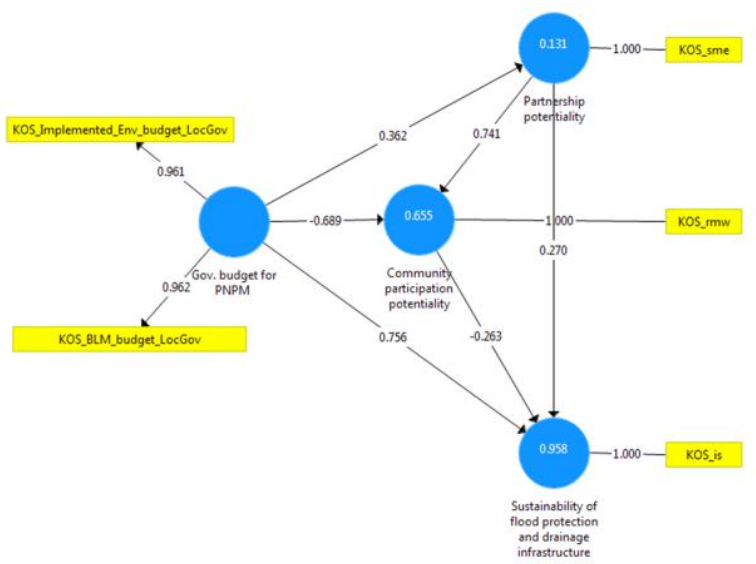

Figure 10 Scenario 2: Kosambi (KOS) polder Weight value

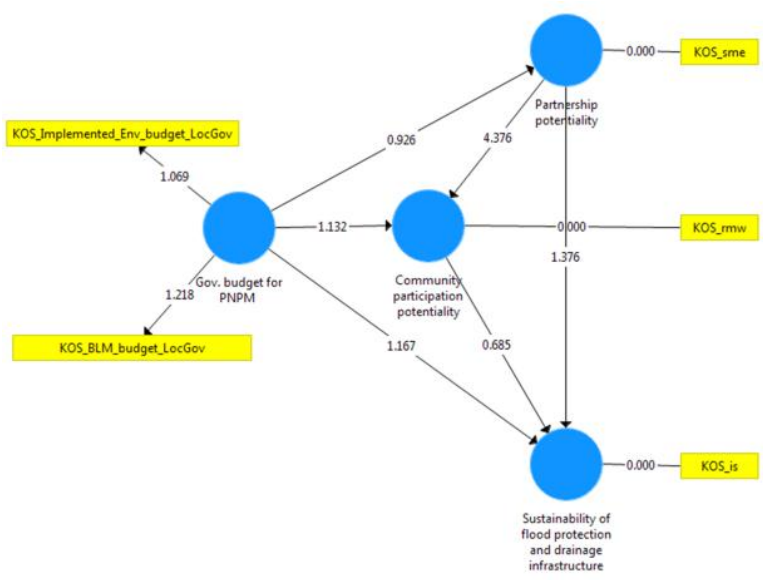

Figure 11 Scenario 2: Kosambi (KOS) polder T-value

Table 8 Scenario 2: Weight and $\mathrm{R}^{2}$

\begin{tabular}{lcccc}
\hline & MK & PL & PM & KOS \\
\hline $\mathrm{R}^{2}$ for Sust.Inf. & n.a. & n.a. & n.a. & $95.8 \%$ \\
$\mathrm{R}^{2}$ for CPP & n.a. & n.a. & n.a. & $65.5 \%$ \\
Gov. Bdg $>$ PP & n.a. & n.a. & n.a. & +0.362 \\
Gov. Bdg $>$ C CPP & n.a. & n.a. & n.a. & -0.689 \\
Gov. Bdg $>$ > Sust.Inf. & n.a. & n.a. & n.a. & +0.756 \\
PP $>>$ CPP & n.a. & n.a. & n.a. & +0.741 \\
PP $>$ Sust.Inf. & n.a. & n.a. & n.a. & +0.270 \\
CPP $>>$ Sust.Inf. & n.a. & n.a. & n.a. & -0.263 \\
\hline
\end{tabular}

Table 9 Direct effect comparison of KOS' scenarios: $\mathrm{R}^{2}$, Weight and T-value

\begin{tabular}{lrrr}
\hline \multicolumn{1}{c}{ Direct Effect } & Scenario 1 & Scenario 2 & Baseline \\
\hline $\mathrm{R}^{2}$ for Sust.Inf. & $73.3 \%$ & $95.8 \%$ & $94.5 \%$ \\
$\mathrm{R}^{2}$ for CPP & $29.3 \%$ & $65.5 \%$ & $66.4 \%$ \\
Gov. Bdg >> PP & +0.725 & +0.362 & +0.784 \\
& $(12.482)^{*}$ & $(0.926)$ & $(6.956)^{*}$ \\
Gov. Bdg > CPP & +0.326 & -0.689 & -0.472 \\
& $(0.408)$ & $(1.132)$ & $(0.910)$ \\
Gov. Bdg > S Sust.Inf. & +0.040 & +0.756 & +1.063 \\
& $(0.024)$ & $(1.167)$ & $(0.649)$ \\
PP >> CPP & +0.255 & +0.741 & -0.390 \\
& $(0.238)$ & $(4.376)^{*}$ & $(0.533)$ \\
PP $>>$ Sust.Inf. & +0.812 & +0.270 & +0.298 \\
& $(0.367)$ & $(1.376)$ & $(0.085)$ \\
CPP > > Sust.Inf. & -0.868 & -0.263 & +0.471 \\
& $(1.393)$ & $(0.685)$ & $(0.118)$ \\
\hline
\end{tabular}

*: significant at $\alpha=5 \%$ or $\mathrm{T}$-value (table) $=1.96$

Table 1o Indirect effect comparison of KOS' scenarios: Weight and T-value

\begin{tabular}{|c|c|c|}
\hline $\begin{array}{c}\text { Indirect } \\
\text { Effect }\end{array}$ & Scenario 1 & Scenario 2 \\
\hline Gov. Bdg $>>$ & $+0.725^{*}(+0.812)$ & $+0.362^{*}(+0.270)=$ \\
\hline $\mathrm{PP} \gg>$ Sust.Inf & $\begin{array}{l}=+0.589 \\
(<\text { baseline of }+1.063) \\
(<\text { direct effect of } \\
+0.040) \\
(0<+0.040>+0.589)\end{array}$ & $\begin{array}{l}+0.098 \\
(<\text { baseline }+1.063) \\
(<\text { direct effect of } \\
+0.756) \\
(0<+0.098<+0.756)\end{array}$ \\
\hline Gov. Bdg $>>$ & $+0.725^{*}(+0.255)^{*}(-$ & $+0.362 *(+0.741) *(-$ \\
\hline $\mathrm{PP}>>C P P>>$ & $0.868)=$ & $0.263)=$ \\
\hline Sust.Inf & $\begin{array}{l}-0.160 \\
(<\text { baseline }+1.063) \\
(<\text { direct effect of } \\
+0.040) \\
(-0.160<0<+0.040)\end{array}$ & $\begin{array}{l}-0.07 \\
(<\text { baseline +1.063) } \\
(<\text { direct effect of } \\
+0.756) \\
(-0.07<0<+0.756)\end{array}$ \\
\hline $\begin{array}{l}\text { Gov. Bdg }>> \\
\text { CPP }>> \\
\text { Sust. Inf. }\end{array}$ & $\begin{array}{l}+0.326^{*}(-0.868)=-0.283 \\
(<\text { baseline }+1.063) \\
(<\text { direct effect of } \\
+0.040) \\
(-0.283<0<+0.040)\end{array}$ & $\begin{array}{l}-0.689^{*}(-0.263)=+0.181 \\
(>\text { baseline }+1.063) \\
\text { (< direct effect of } \\
+0.756) \\
(0<+0.181<+0.756)\end{array}$ \\
\hline
\end{tabular}

Following MK_is predictor disqualification then scenario-2 left KOS as the single object for SFM assessment (Table 7). Table 9 shows that with regards to the direct effect of Gov_bdg >>Sust.Inf. scenario 1 has a better Weight value $(+0.040)$ while scenario 2 has a better T-value despite still being insignificant (1.167) with Weight value +o.756. Empirically, the Weight value of scenario 1 reflects the condition where Local Government programs had not purposely intended to impact on the illegal dwellers in terms of protecting, alleviating, or providing an exit strategy.

Scenario 2, on the other hand, reflects differences as compared to the baseline $(+1.063)$ in the sense that Local Government programs did not endorse the illegal acitivities 
related to the urban polder assets, while at the same time they provided social schemes through which an exit towards better conditions was available. Among the two, scenario 2 is more feasible as it has a Weight value below the baseline and was more stable in terms of contribution and impact to the Sust.Inf.

As explained in Table 1, NPCE-type programs were intentionally designed to create collaboration among the National Government, Local Government, community (including the poor), and private sectors. In SFM assessment, that concept can be analyzed through SEMPLS's path analysis or indirect analysis. Selection criteria for the results are value $<$ baseline $(+1.063), 0<$ value $<$ direct effect of scenario $1,0<$ value $<$ direct effect of scenario 2 .

Table 10 shows that scenario 2 provides two expected results : (i) Gov. Bdg >> PP >>Sust.Inf $=+0.098$ and (ii) Gov. $\mathrm{Bdg} \gg>\mathrm{CPP} \gg>$ Sust. Inf. $=+0.18$. The first result is composed of the positive Weight value which reflected the NPCEtype's collaborative feature for correlative improvement among program, budget and target group's environmentalsocial conditions. The second result is composed of the negative values which opposed the NPCE-type program's features and hence was not empirically implemented. Based on this result, the indirect effect of Gov. Bdg >> $\mathrm{PP}>>$ Sust.Inf $(+0.098)$ is the more feasible among the two.

Table 11 Compilation of Scenario's Feasible Results

\begin{tabular}{lrrr}
\hline & $\begin{array}{c}\text { Scenario 1 } \\
\text { (Regular- } \\
\text { type based) }\end{array}$ & $\begin{array}{c}\text { Scenario 2 } \\
\text { (NPCE-type } \\
\text { based) }\end{array}$ & $\begin{array}{c}\text { Baseline } \\
\text { (Regular-type } \\
\text { based) }\end{array}$ \\
\hline Direct Effect & +0.040 & +0.756 & +1.063 \\
Indirect effect & $(0.024)$ & $(1.167)$ & $(0.649)$ \\
& none & +0.098 & \\
\hline
\end{tabular}

*: significant at $\alpha=5 \%$ or $\mathrm{T}$-value (table) $=1.96$

Table 11 finds that for better Gov_bdg>>Sust.Inf. value then scenario 1 has regular-type value of +0.040 and NPCEtype value of +0.756 . According to the regular-type and NPCE-type characteristics (Table 1) then empirically the lower value of the regular-type indicated a total detachment from illegal dwellers alleviation while the NPCE-type value indicated labour-intensive infrastructure provisions along with social program which enhanced empowerment.

The indirect effect result of scenario 2 has a value of +0.098 through path Gov_bdg $\gg>P P \gg>$ Sust,Inf. which indicated that the effect of Local Government's NPCE-type program might affect the target-group through involvement of and continuity given by the private sector.

For a Local Government to make improvements, directly or indirectly, from the Gov_bdg>>Sust.Inf. segment then to adopt NPCE-type program would be a reasonable choice. As the direct effect of Gov_bdg>>Sust.Inf. is a Local Government mandate, then scenario 2 (direct effect)
$($ Weight value $+0.756($ T-value $=1.167))$ would be the best option.

\section{Conclusion}

The general Sustainable Financial Model (SFM) of DKI Jakarta urban polders have set certain values which may act as a baseline which individual polders can follow. However those baseline values are dynamic and also improve gradually. Among the values which critically needed to be adjusted was the segment of Gov_bdg>>Sust.Inf. as (i) Local Government holds the mandate in terms of budget to manage the development in accordance to the regulations and (ii) in most cases DKI Jakarta urban polders were at the stage in which illegal dwellers affected flood protection and urban drainage performance.

Regarding the objective to find better values as compared to SFM's Gov_bdg>>Sust.Inf. baseline then there are two scenarios which can be simulated under variable Gov_bdg: (i) regular-type which uses the indicator of flood_drain_budget_LocGov and (ii) NPCE-type which uses the combined indicators of _implemented_env_budget_LocGov _implemented_BLM_budget_LocGov.

Initial simulation (scenario 1 ) for all individual polders reveals that SFM assessment of individual polders has better values compared to the baseline as follows: KOS's Gov. Bdg >> PP , PM's Gov. Bdg >> CPP, KOS's Gov. Bdg >> Sust.Inf., KOS's PP > CPP, KOS's PP >Sust.Inf., KOS's CPP >> Sust.Inf, with significant results obtained by KOS's Gov_bdg $>>P$ P. Higher values in individual polders as compared to the Local Government SFM baseline value can indicate an asset from which Local Government may learn for the improvement of other polders. Scenario 1 results for Gov_bdg $>>$ Sust.Inf. also had PM value of +0.682 and KOS value of +0.040 . Both values were lower than the baseline of + 1.063. However, empirical facts of PM's illegal dwellers reduction was an impact of particular programs outside the flood protection and drainage control program. For that reason, this step selected theKOS value (Weight $=+0.040$, $\mathrm{T}$-value $=0.024$ ) for further assessment.

Scenario 2 consisted of 2 sub scenarios: direct effect and indirect effect (path analysis) simulations. The indirect effect was investigated due to NPCE-type program feature which internalized collaboration among stakeholders (Government, community, private sectors). With regards to direct results, KOS' direct effect had Weight value of +0.756 (T-value=1.167) while its indirect effect had a value of + 0.098 through path Gov_bdg $>>P P>>$ Sust,Inf.

Final comparison for all results led to the scenario 2 (direct effect) showing the most feasible results (Weight 
value +0.756 and $\mathrm{T}$-value $=1.167)$ which means that for a Local Government to make a difference or improvement from the Gov_bdg>>Sust.Inf. segment then to adopt NPCEtype program would be the best option.

Areas within the urban polders of DKI Jakarta have been experiencing the NPCE-type since year 2007 with Local Government involvement throughout the implementations. In term of Gov_bdg>>Sust.Inf., SFM assessment in which NPCE-type indicators were involved were shown to give better values as compared to the baseline.

\section{References}

[1] Segeren WA. Polders of the World. Wageningen, the Netherlands: International Institute for Land Reclamation and Improvement; 1983.

$[2,4,5]$ Naskah akademik RTRW DKI Jakarta 2010-2030, Jakarta, Indonesia: Badan Perencanaan dan Pembangunan Provinsi DKI Jakarta; 12 Januari 2010

[3] Joint Working Group. Urban Polder Guidelines Volume 2: Institutional Aspects. p. 7-11. Semarang, Indonesia: Balitbang PU-Puslitbang SDA, Rijkswaterstaat, UNESCO-IHE; 2009

[6] Winaktoe Wied W, Schultz B, Suryadi FX. Model Development on the Sustainable Financial Aspects of Urban Polders in The Province of DKI Jakarta. International Journal of Sustainable Future for Human Security (J-SustaiN) Vol. 5 No.2; 2017

[7] Tibaijuka Anna Kajumulo. The Challenge of Slums: Global Report on Human Settlements 2003, USA: Earthscan Publication Ltd; 2003, p. 212

$[8,10]$ Priatmodjo Danang. Winning Back City's Blue-Green Elements: Cases of Waduk Pluit and Waduk Ria Rio, Jakarta. Italy: $53^{\text {rd }}$ International Making Cities Livable Conference on Caring For Our Commomn Home; 2016, p.2

[9] Lin-heng Lye Irene, Harvey Neo, Kondepudi Sekhar, Wen-Shan Yew, Gek-Khim Judy Sing. Sustainability Matters: Environmental Management In The Anthropocene. Singapore: World Scientific Publishing Co.Pte.Ltd. ; 2017: p. 455

[11] Cuadra Linda Kathleen. This Grievable Life: Precarity, Land Tenancy, and Flooding in the Kampung of Jakarta. p.22. USA: University of Washington; 2015

$[12,18]$ Bricker Jeremy D, Kure Shuichi, Muhari Abdul, Fukutani Yo, Hanan Firmanto. IRIDeS Fact-finding missions to Jakarta, Indonesia. p.30 and p.43. Japan: Tohoku University; 2013

[13] Cahyadi Rusli. Kaum Miskin Kota, Sampah, dan Rumah; Studi tentang Akses Migran Miskin terhadap Sumber Daya Lingkungan dan Perumahan di Tangerang. Jurnal Sosiologis "Masyarakat" Vol. 16 No 1 Januari 2011: P. 82

[14] Anonim. Kebijakan Penanggulangan Banjir di Indonesia. p.12. Jakarta: Bappenas, Deputi Bidang Sarana dan Prasarana, Direktorat Pengairan dan Irigasi; 1996

[15] Team Mirah Sakethi. Mengapa Jakarta Banjir: Pengendalian Banjir Pemerintah Provinsi DKI Jakarta. Jakarta: PT Mirah Sakethi; 2010: p. 39

[16] Peraturan Menteri Pekerjaan Umum Nomor o1/PRT/M/2014 Tentang Petunjuk Teknis Standar Pelayanan Minimal Bidang Pekerjaan Umum dan Penataan Ruang. p. 30. Jakarta:Kementerian Pekerjaan Umum; 2014

[17] Winaktoe Wied W, Schultz B, Suryadi FX. DKI Jakarta's Polder development vision 2030: Assessing the progress and identifying policy needs based on the polder board model. Jakarta: Universitas Tarumanagara; 2015

[19] Farha Leilani. Report of the Special Rapporteur on adequate housing as a component of the right to an adequate standard of living, and on the right to non-discrimination in this context on her mission to Indonesia. p.10 and 17. USA: UN Commission on Human Rights ; 2013

[20] Anonim. Ulasan Upaya Perlindungan Negara Indonesia: Appendix 11 Kajian Akseptibiltas Pemukiman Kembali Tidak Secara Sukarela per Sektor. p.34. Jakarta: Asian Development Bank; 2017

[21, 33] BPS DKI Jakarta. Analisis Tipologi Kemiskinan Perkotaan, Jakarta: Badan Pusat Statistik, 2007, p. 40-41

[22] Suharyo Widjajanti L, Sulaksono Bambang, Widjanarko Herry, Toyamah Nina, Fillaili Rizki, Usman Syaikhu, Heryawan Wawan. Peningkatan Kapasitas Pemerintah Daerah dalam Penanggulangan Kemiskinan melalui Analisis Kemiskinan Partisipatoris (AKP). p. 47-48. Jakarta: Lembaga Penelitian SMERU; 2006

[23, 28] http://sim.p2kp.org/pnpm/?act=default_home

[24] Anonim. Pedoman Teknis Kegiatan Tridaya (Sosial, Ekonomi, dan Lingkungan). Jakarta: Direktorat Jenderal CIpta Karya; 2012: p. 12-49

[25] Gonzalez Raul P, The Indonesian Program Nasional Pemberdayaan Masyarakat Mandiri: Lessons For Philippine Community-Driven Development. p.12-14. Philippines: Asian Development Bank; 2012

[26] Anonim. Penilaian Kota Mandiri. p.1. Jakarta: Direktorat Jenderal Cipta Karya, Kementerian Pekerjaan Umum dan Perumahan Rakyat; 2015

[27] http://data.jakarta.go.id/dataset?q=anggaran\&tags=APBD

[29] Monecke Armin, Leisch Friedrich. semPLS: Structural Equation Modeling Using Partial Least Squares. Journal of Statistical Software. 48(3); 2012: p. 1-32.

[30] Ghozali I, Structural Equation Modeling with Partial Least Square (PLS). Semarang, Indonesia: Badan Penerbit Universitas Diponegoro; 2011, p. 4

[31] Garson David G. Partial Least Squares: Regression \& Structural Equation Models. Asheboro, NC, USA: Statistical Publishing Associates; 2016: p. 28-29.

[32] Hair Jr Joseph F, Ringle Christian M, Sarstedt Marko. Partial Least Squares Structural Equation Modeling: Rigorous Applications, Better Results and Higher Acceptance. Long Range Planning, Vol 46 (2013) 1-12; 2013, p. 2

[34] Haryati Aprilia Bela, Wardani Afiati Indri . Analisis Peran Aktor dalam Pelaksanaan Relokasi Warga Waduk Ria-Rio keRusun Pinus Elok dan Rusun Cakung Barat Jakarta Timur. p.9-13. Jakarta: Departemen Ilmu Administrasi, FISIP UI; 2016 